\title{
Research on Teaching Reform of Visual Communication Design Specialty in Digital Media Era
}

\author{
$\mathrm{Hu} \mathrm{Bo}^{1, \mathrm{a}}$ \\ ${ }^{1}$ School of Art and Design, Hubei Engineering University \\ a kavana1011@126.com
}

\begin{abstract}
Keywords: Digital media era; Visual communication design; Professional personnel training
\end{abstract}
\begin{abstract}
The advent of the digital era has driven the constant innovation and innovation of professional teaching. Under the digital vision, the visual communication design professionals training model needs innovation. This article mainly elaborates the problems in the cultivation of visual communication design professionals, and puts forward professional teaching reform strategies, aiming to optimize the professional teaching and improve the quality of personnel training.

With the rapid advent of market economy and digital information technology, the society has raised new requirements for professional personnel training, and the design field also has its own opinions. The era of digital media has brought opportunities for the development of the design field. Under this background, the visual communication design professional teaching is also undergoing continuous self-innovation. Colleges and universities should review their current professional teaching in a timely manner, find out in a timely manner the current deficiencies in the process of personnel training, and combine new teaching methods and student development needs to promote teaching innovation.
\end{abstract}

\section{The Status Quo of Visual Communication Design Professionals}

The Lack of Practical Application Suited to the Development of the Industry for Professional Talents

The rapid development of the design field has caused great changes in the industry. With the rapid development of digitalization and informatization, the development of traditional industries has been hindered, and emerging industries seeking help for digitization and informationization have shown vigorous development. The collision of new and old industries has made the demand for professional talents in society appear diversified. Specifically, the training of visual communication design professionals in colleges and universities neglects the current status of social development and the actual needs of professionals, and still carries out teaching work in accordance with the traditional professional curriculum teaching model. The graphic design courses account for a large proportion, and are digitized. There are almost no courses, resulting in students being somewhat hindered in terms of professional competence. In addition, the partial teaching of professional teaching leads to the lack of practical application ability of professional talents, and the innovative thinking needs to be improved.

The Training of Digital Professionals Needing to be Improved

The era of digital media provides a vast space for the development of art design. Visual communication design is an important part of art design. It must be assisted and promoted by digital art in the process of professional development. However, in this process, problems have arisen in the teaching of professional courses and the training of talents in universities. The goal of training talents for visual communication professionals and the goal of educating digital professionals cannot be effectively unified. This will affect the quality of professional personnel training to some extent. , it can not meet the quality needs of professionals in the digital era.

Insufficient Professional Curriculum System

Although many colleges and universities have realized the necessity and importance of the teaching reform of visual communication design, their understanding of digital information teaching needs to be further improved. Most of them are only innovative teaching methods, and actively introduce some digital teaching. Equipment, but it ignores the construction of a professional course system. Digital information teaching is not only the digitization of teaching methods, but also reflected in the course construction. In addition, although some schools have incorporated digital art courses in the curriculum system, such as digital media design, web page design and other professional courses, their professionalism and comprehensiveness have yet to be improved, and class teaching is also inadequate. There are limited professional teaching hours. Internally, teachers cannot fully introduce the content knowledge of digital courses to students, and students' design theory learning needs to be improved. 


\section{Reform Strategy of Visual Communication Design Professional Teaching in Digital Media Era}

\section{Innovate the Teaching Idea And Improve the Construction of Professional Course System}

In terms of personnel training, colleges and universities should actively innovate their own teaching philosophy, timely review their own deficiencies in the training of professional personnel, keep up with the trend of the times, and effectively integrate the digital spirit and the spirit of the times into the professional teaching process. Colleges and universities should first understand the development status of the visual communication design industry and its quality requirements for talents. In combination with the actual teaching of the school, the university should redefine its own talent training program. The visual communication design major is a comparatively comprehensive art discipline. Teachers should balance the ratio between theoretical teaching and practical teaching in the construction of professional curriculum systems. Traditional professional curriculum teaching and digital curriculum teaching should also be considered, thus improving visual communication. Design professional curriculum system construction. First of all, combining the students' professional development needs, we will perfect the visual communication design professional teaching unit and actively create some comparisons to break the limitations of traditional professional teaching and improve the openness and professionalism of professional teaching. Secondly, actively develop interdisciplinary professional teaching, and effectively combine graphic design with digital teaching. Students can not only contact with visual communication design expertise, but also have access to relevant digital and informatization expertise, and many professional courses. Cross each other to improve the comprehensive teaching. Finally, the school must combine its own development reality, increase capital investment, and actively introduce some digital teaching equipment to provide students with digital learning possibilities.

\section{Strengthen Practical Teaching and Improve the Practical Application of Professionals}

Although the visual communication design profession is a comprehensive specialty that combines theory with practice, combined with the development of talents in the industry, it should focus on cultivating students' practical application skills in the teaching process, following the professional teaching practice and the development of disciplines. Based on the law, students' abilities in humanities and arts cultivation and theoretical connection with practice are improved. First of all, schools can strengthen cooperation and exchanges with other colleges and universities, and conduct discussions on professional skills development and promotion of comprehensive literacy, so as to form a concerted effort to effectively integrate educational resources and fully display the effectiveness of cooperation so as to avoid the waste of educational resources. Second, colleges and universities should strengthen cooperation with related companies, give full play to their own teaching advantages, and focus on cultivating high-quality comprehensive professional personnel. Effectively combine domestic design with foreign design, and then actively develop individualized professional teaching based on the characteristics of students' learning, enrich the expression of visual design, and improve the practical performance of the professional training. Finally, focus on the cultivation of innovative and entrepreneurial talents. The joint society will build a platform for students' innovative ability. Make full use of the openness of the teaching of art disciplines, strengthen communication with the market, actively tap students' internal potential, improve students' artistic accomplishments, expand students' thinking, and develop suitable professional talents for the industry.

\section{Actively Carry out Project Teaching and Train Students' Innovative Thinking Skills}

Under the age of digital media, the teaching of art majors is to break the limitations of traditional teaching ideas and the constraints of design ideas. Therefore, the current teaching focus of schools should be focused on cultivating students' innovative thinking, and effective divergent thinking and reverse thinking should be effective. Infiltrated in professional teaching. Project teaching is a teaching mode that is widely used in current university teaching. It aims to improve the students' professional qualities and creative thinking ability through the project. With the help of the project teaching method to actively develop visual communication design professional teaching, we must first clarify the teaching objectives, focus on cultivating students' practical application ability, aesthetic ability, personalized design style and cooperative inquiry skills, and ultimately promote students' comprehensive and all-round development. Secondly, formulate project plans and actively carry out project-based learning through group cooperation. Each team member communicates with each other, specifies learning projects, and formulates detailed project plans. Finally, project evaluation. Project evaluation is mainly divided into teacher evaluation and student evaluation. In the process of teacher evaluation, the teacher should comprehensively review the project completion status and specific implementation status of each group, and praise the excellent team, and give full play to the exemplary role of the model. Student evaluation is mainly divided into student self-evaluation, group evaluation, and evaluation of each group. Students are fully aware of their own advantages and disadvantages in the project learning process as well as the advantages and disadvantages of others, so as to constantly improve themselves and stimulate their own internal driving force. To promote their professional growth. The project-based teaching through group cooperation can not only improve the students' professional ability, but also cultivate the students' collective spirit and promote the students' cooperative exploration ability.

Using Internet Teaching Resources to Broaden The Horizon of Students' Professional Learning

In the digital media era and the Internet+ environment, there are many high-quality teaching resources. To help 
students to better complete professional learning, the school can actively build an e-learning and communication platform. Students can find many in this e-learning and communication platform. Extracurricular learning resources save time and effort, greatly improving the efficiency of their own learning. Teachers can combine their own professional teaching advantages, recommend some information about visual communication design professional to students, recommend some relatively outstanding design companies, let students understand their employment standards, and provide students with the right value orientation for professional learning. College students have a strong ability to use the Internet and electronic information technology. They can provide more materials for their own professional learning through the Internet, broaden their professional vision of learning, and actively develop brainstorming to promote themselves. The all-round development will improve its own competitive advantage. The Internet effectively integrates words, voices, and ideas, breaking the limitations of traditional teaching in terms of time and space, and providing a driving force for the cultivation of diverse talents.

\section{Conclusion}

Visual communication design is an important part of the construction of professional course system in colleges and universities. It has trained a group of professional talents for the field of design in China. The advent of the digital media era has given directions to the design of visual communication design. Therefore, school teachers must follow the rules and characteristics of professional teaching, effectively integrate digital media technology and professional teaching, and thus promote the sustainable development of visual communication design professional teaching. It also cultivates more innovative talents for China's design field.

\section{References}

[1] Liu Tianjiao. The practice and research of project teaching method in the visual communication course in the digital media era [J]. Beauty and Times (top), 2015 (12): 126-128.

[2] Long Jian. Innovative exploration of the visual communication professional logo design course in the new media era [J]. Theatre Home, 2016(06): 170.

[3] Ren Xiaxia. Problems and Reforms in the Teaching of Visual Communication Design[J]. Modern Decoration (Theory), 2017(02):261-262. 